„Kwartalnik Filmowy” nr 115 (2021)

ISSN: 0452-9502 (Print) ISSN: 2719-2725 (Online)

https://doi.org/10.36744/kf.863

(c) Creative Commons BY-NC-ND 4.0

\title{
Paweł Biliński
}

Uniwersytet Gdański

https://orcid.org/oooo-0002-4724-4542

\section{Studia nad historią. Brechtowskie filmy Radu Judego}

\author{
Słowa kluczowe: \\ Radu Jude; \\ Rumunia; \\ Bertolt Brecht; \\ rekonstrukcja; \\ efekt obcości; \\ intertekstualność
}

\begin{abstract}
Abstrakt
Artykuł jest poświęcony twórczości Radu Judego - rumuńskiego reżysera, który po wyprodukowanym w 2015 r. Aferim! stale eksplorował tematykę historyczną. Autor przedstawia podstawowe koncepcje rozumienia filmu historycznego (odwołując się przy tym do ustaleń Williama Guynna czy Roberta Rosenstone'a) i szkicowo prezentuje estetyczno-narracyjne dominanty nowego kina rumuńskiego XXI w., by na tym tle odczytać dzieła Nie obchodzi mnie, czy przejdziemy do historii jako barbarzyńcy (Îmi este indiferent daca în istorie vom intra ca barbari, 2018) oraz Drukowanymi literami (Tipografic Majuscul, 2020) - dwa fabularne filmy Judego, w których reżyser, wyraźnie inspirując się teorią Bertolta Brechta, rozwija poetykę kina modernistycznego. Skupiając się na problematyce historycznej, którą analizuje za pomocą chwytów refleksywnych, Jude zdecydowanie zrywa z tematycznymi tendencjami kina Rumunii ostatnich kilkunastu lat.
\end{abstract}


Kiedy w 2015 r. Radu Jude, twórca reprezentujący tak zwane nowe kino Rumunii, na festiwalu w Berlinie pokazywał Aferim!, mało kto mógł przypuszczać, że z czasem będziemy mogli ów film uznać za moment zwrotny w karierze tego autora. Przed nakręceniem czarno-białego easternu, którego akcja rozgrywała się na terenie Wołoszczyzny w XIX w., Jude był postrzegany przede wszystkim jako utalentowany uczeń Cristiego Puiu (autora Śmierci pana Lazarescu /Moartea domnului Lăzărescu, 2005/, na której planie Jude pełnił funkcję asystenta reżysera), bacznie obserwujący współczesne społeczeństwo Rumunii, sportretowane przez niego w Najszczęśliwszej dziewczynie na świecie (Cea mai fericită fată din lume, 2009) czy Wszystkich w naszej rodzinie (Toată lumea din familia noastră, 2012). W historycznym Aferim! Jude skoncentrował się zaś na postaciach żyjących w czasach niekoniecznie zajmujących rumuńskich reżyserów. Film zaskakiwał nie tylko niespotykaną dotąd rewizją krytyczna, ale także płaszczyzną audiowizualną. Głównych bohaterów kamera najczęściej obserwowała z dużej odległości, co pozwoliło odbiorcom utrzymać swoisty dystans, spotęgowany faktem, że trudno w Aferim! o wielkie plany, które mogłyby pomóc w poznaniu emocji postaci. Sugestywną estetykę dzieła wspierały dosadne dialogi, ujawniające skalę ksenofobii i prostoty w sposobie myślenia mieszkańców Wołoszczyzny tego okresu. Przy pracy nad scenariuszem Jude oraz Florin Lăzărescu posiłkowali się archiwalnymi dokumentami, pozwalającymi rozpoznać dyskurs osób wierzących w rzekomo praworządny charakter feudalnego porządku' ${ }^{1}$.

Dwie kwestie wydają się tu szczególnie znamienne. Po pierwsze: dążenie twórców do stworzenia określonej sytuacji odbiorczej dzieła, a po drugie: przygotowanie scenariusza na podstawie nie tyle literatury (a przynajmniej nie tylko literatury ${ }^{2}$ ), ile pism dokumentujących historię regionu, które w dużym stopniu pozwoliły uzyskać realistyczny obraz Wołoszczyzny 1835 r. Jude zamierzał bowiem zrealizować film oryginalny zarówno w sferze poetyki, jak i poruszanej problematyki. Nie mniej istotna okazuje się metoda pracy Judego (i innych członków ekipy). To właśnie przy okazji produkcji Aferim! rumuński twórca odkrył w sobie pasję przeglądającego stare materiały historyka, który na ich podstawie przygotowuje grunt pod przyszły utwór. Wnikanie w archiwa jest o tyle istotne, że stanie się tematem przyszłych projektów autora Wszystkich w naszej rodzinie.

W niniejszym szkicu chciałbym się przyjrzeć bliżej dwóm dziełom Judego, potwierdzającym, jak duży wpływ miała na niego praca przy Aferim! Pierwsze z nich, wyróżnione Kryształowym Globusem w Karlowych Warach Nie obchodzi mnie, czy przejdziemy do historii jako barbarzyńcy (Îmi este indiferent daca în istorie vom intra ca barbarii, 2018), odnosi się do reżimu marszałka Iona Antonescu, premiera Rumunii w latach 1940-1944. Z kolei drugi film, Drukowanymi literami (Tipografic Majuscul, 2020), nawiązuje już do wydarzeń mających miejsce w ostatniej dekadzie panowania Nicolae Ceaușescu. W obu filmach Jude kieruje się w stronę problemów, które niechętnie były podejmowane przez pozostałych reżyserów reprezentujących nowe kino Rumunii, a już na pewno nie w taki sposób, w jaki on im się przyjrzał. By jednak lepiej zrozumieć ów zwrot w jego twórczości, trzeba także odwołać się do dominujących w tamtejszej kinematografii komponentów estetycznych, które w dużym stopniu zunifikowały sposoby interpretowania najważniejszych filmów tego nurtu. Kolejna część studium będzie się koncentrować na analizie formy i treści wspomnianych dzieł, ujmowanych nie tylko przez pryz- 
mat najbardziej znaczących tendencji rumuńskiej kinematografii, ale przede wszystkim jako filmów historycznych korzystających z instrumentarium teorii Bertolta Brechta.

\section{W stronę minimalizmu (i polityki)}

O fenomenie rumuńskich filmów produkowanych po 2005 r., a więc po premierze Śmierci pana Lazarescu, napisano już dość dużo ${ }^{3}$; także w Polsce ukazało się kilka mniej lub bardziej pogłębionych opracowań ${ }^{4}$. Lektura poszczególnych szkiców przekonuje, że podstawowym kluczem interpretacyjnym - łączącym dzieła twórców tak różnych, jak Cristian Mungiu, Radu Muntean czy Corneliu Porumboiu - było odczytywanie rumuńskich filmów XXI w. jako takich, w których operuje się minimalizmem: w zakresie filmowej inscenizacji, czasu akcji (nierzadko sprowadzonej do kilku godzin, najwyżej doby), liczby bohaterów i ukazywanych na ekranie przestrzeni czy stosowania długich ujęćs. Poszczególne środki narracyjne służyły budowie spowolnionego rytmu opowieści ${ }^{6}$, znaczącej redukcji elementów nazbyt zwracających na siebie uwagę (stąd w filmach tych rzadko jest stosowana muzyka ilustracyjna), wreszcie, co wiąże się z poprzednimi komponentami, manifestacyjnej redundantności względem filmów charakteryzujących się większą potoczystością narracyjną. Zainicjowany przez Puiu - raczej przez jego debiut Towar i kasa (Marfa şi banii, 2001) niż, jak wielu twierdzi, opowieść o panu Lazurescu - fenomen, który został przypieczętowany canneńskimi sukcesami 4 miesięcy, 3 tygodni i 2 dni Mungiu i California Dreamin' (Nesfârşit, 2007) Cristiana Nemescu, z miejsca zwrócił uwagę krytyków filmowych, selekcjonerów programowych festiwali oraz entuzjastów kina art-house'owego. Jednym z często docenianych elementów filmów wspomnianych reżyserów był sposób, w jaki pokazywali oni współczesność. Szkicując uniwersalny portret dzisiejszej Rumunii, nie zapominali o jej trudnej historii - komunistycznym reżimie Ceaușescu czy rewolucji 1989 r., w wyniku której ostatni dyktator kraju wraz ze swoją żoną Eleną został osądzony i stracony. Trzeba jednak zaznaczyć, że odniesienia do politycznych dziejów kraju nie zawsze wiązały się z wielopłaszczyznowym rozliczeniem. Obok obrazów defetystycznych (zob. 4 miesiace, 3 tygodnie i 2 dni) i przenikliwych satyr (choćby 12:08 na wschód od Bukaresztu / A fost sau n-a fost?, reż. C. Porumboiu, 2006/) czy filmów proponujących chłodną analizę postkomunizmu (czego dowodem Policjant, przymiotnik), pojawiały się także dzieła, w których do przeszłości wracano z odczuciem nostalgii (bodaj najwyrazistszym przykładem tego typu utworu pozostają nowelowe Opowieści Złotego Wieku /Amintiri din epoca de aur, 2009/, wyreżyserowane przez kilkoro twórców, w tym Cristiana Mungiu) ${ }^{7}$. Rafał Syska, analizując filmy rumuńskie z ostatnich lat, zaznacza, że pokazują one wspótczesna Rumunię jako kraj skażony przeszłościa, pokutujacy za dawne grzechy, próbujacy albo nie pamiętać i żyć teraźniejszościa, albo wracać do historii, szukajac tam przyczyn dzisiejszej atrofii, poczucia obcości i egzystowania w społecznej separacji ${ }^{8}$.

Do momentu premiery Aferim! Radu Jude zdawał się reżyserem reprezentującym podobne podejście do przeszłości. Toksyczne relacje rodzinne sportretowane przez niego w dwóch pierwszych pełnych metrażach oglądamy, mając w pamięci dzieła jego poprzedników, przez co jesteśmy skłonni doszukiwać się wszelkich, choćby nieoczywistych odniesień do (post)komunizmu' ${ }^{9}$ Nie ma jednak 
wątpliwości, że w tematycznym centrum Najszczęśliwszej dziewczyny na świecie i Wszystkich w naszej rodzinie jest przede wszystkim funkcjonowanie najmniejszej komórki życia społecznego ${ }^{10}$, do czego - na swój sposób - odnosi się także Aferim!, w którym śledzimy podróż ojca i syna ${ }^{11}$.

Mimo to reprezentanci nowego kina rumuńskiego, jak zaznacza Christina Stojanova, zwykle unikali zaangażowania i wyrażania wprost deklaracji natury socjologicznej, politycznej czy ideologicznej ${ }^{12}$. Refleksja nad dziejami jako taka z rzadka zajmowała centralne miejsce $\mathrm{w}$ ich tekstach audiowizualnych, co może się wiązać z chęcią wyraźnego zerwania z tendencjami produkcyjnymi tamtejszej kinematografii w XX w., kiedy to kino historyczne cieszyło się największą popularnością wśród widzów (co potwierdzają wyniki box office' $\mathbf{u}^{13}$ ). Za paradygmatycznego reżysera epickich filmów historycznych uchodził Sergiu Nicolaescu, twórca między innymi docenionych przez publiczność Walecznych przeciw rzymskim legionom (Dacii, 1967) czy Michała Walecznego (Mihai Viteazul, 1971) ${ }^{14}$. Co dla nas istotne, do jednego z dzieł Nicolaescu odwołuje się Radu Jude w Nie obchodzi mnie... - i jest to komentarz nadzwyczaj krytyczny ${ }^{15}$.

\section{Film historyczny, film o historii}

Warto na chwilę zatrzymać się przy problemie kina skoncentrowanego na prezentowaniu przeszłości. W refleksji teoretycznej od początku zmagano się z tym, czym film historyczny powinien się charakteryzować, oczywiście poza tym, że ma traktować o historii. Wydaje się to dość klarowne z punktu widzenia odbiorcy - z filmem historycznym mamy do czynienia wtedy, gdy opowiada on o wydarzeniach rozgrywających się w mniej lub bardziej oddalonej przeszłości i gdy odnosi się do ważnych zjawisk czy postaci znanych (przede wszystkim, choć nie tylko) z literatury specjalistycznej poświęconej danemu okresowi. Gdy oglądamy takie filmy, jak Wojna i pokój (Wojna i mir, reż. S. Bondarczuk, 1966-1967), Potop (reż. J. Hoffman, 1974) czy Lincoln (reż. S. Spielberg, 2012), nie mamy większych wątpliwości, że to filmy historyczne, nawet jeśli korzystają z języka czy estetyki odmiennych gatunków ${ }^{16}$. Czas akcji jest jednak w tym wypadku kwestią cokolwiek problematyczna, bo nie jesteśmy w stanie jednoznacznie stwierdzić, jak odległa przeszłość zaprezentowana na ekranie może kwalifikować dany film do tego, by określić go mianem historycznego ${ }^{17}$. Pytanie to zadawała choćby Elżbieta Durys, przywołując między innymi opinię Davida Eldridge’a, autora książki Hollywood History Films, który zaproponował kryterium pięć lat od momentu, gdy dany film powstanie $^{18}$, co zdaniem badaczki (i sam przychylam się do tej opinii) nie jest kryterium wystarczającym ${ }^{19}$. Durys proponuje więc traktować film historyczny jako termin parasolowy, dzięki czemu można go ująć jako kategorię, która obejmuje szereg pomniejszych, mniej lub bardziej wyemancypowanych gatunków ${ }^{20}$ : film biograficzny, wojenny, płaszcza i szpady, batalistyczny, kino dziedzictwa narodowego i inne.

Odmienny podział, bardziej odnoszący się do sposobów podejmowania tematów historycznych, zaproponował swego czasu William Guynn, autor książki Writing History in Film, w której wyróżnił dwa podstawowe rodzaje tego typu filmów: dokument historyczny, którego cecha wyróżniajaca jest to, że odnosi się do dokumentów, obrazów archiwalnych, sfilmowanej (...) spuścizny, lektury tekstów historycznych, wspótczesnych ujęć miejsc historycznych, wywiadów ze świadkami historii lub 
historykami, oraz fabularny film historyczny, w ramach którego reżyser dokonuje rekonstrukcji wydarzeń przed kamera, wykorzystując środki mise-en-scène i tworząc fikcjonalne podwojenie ${ }^{21}$. Zwracam uwagę na oba typy filmów, bo wspomniane przez Guynna elementy - zarówno dokumentu, jak i filmu fabularnego można odnaleźć w interesujących nas dziełach Judego. Jednocześnie nietrudno sobie wyobrazić widza, który po projekcji wskazanych filmów rumuńskiego autora niekoniecznie byłby skłonny nazwać je utworami historycznymi. Odnoszą się one bowiem do historii, ale na zupełnie innych zasadach aniżeli filmy, które zwykliśmy przyporządkowywać do wspomnianej kategorii. Nie obchodzi mnie... i Drukowanymi literami ukazują wydarzenia z przeszłości, lecz ich twórcy korzystają ze współczesnej scenografii, w obu filmach ważną funkcję pełnią chwyty autotematyczne i zostaje uwypuklona idea rekonstrukcji oraz teatralność jako taka, oba wreszcie sytuują w centrum narracji nie tylko historię Rumunii, ale też to, jak była ona problematyzowana i podejmowana przez artystów czy historyków. Jude traktuje medium audiowizualne jako narzędzie służące nie tylko do przedstawiania fikcjonalnej (choć odnoszącej się do faktów) fabuły, ale też do analizowania przeszłości oraz tego, jak wpływa ona (i jak może wpływać) na współczesność 22 . Pod tym względem jego dzieła - zwłaszcza te zrealizowane po Aferim! - sytuują się na antypodach kina kojarzonego w Rumunii z koturnowymi superprodukcjami w reżyserii Nicolaescu.

\section{Niuanse rekonstrukcji}

Spośród wymienionych wyżej pojęć zwróciłbym szczególną uwagę na rekonstrukcję, która w kontekście historii kina rumuńskiego nie jest niewinna. Wiąże się to z faktem, że za kluczowe arcydzieło tamtejszej kinematografii uchodzi Rekonstrukcja (Reconstituirea, 1968) Luciana Pintiliego ${ }^{23}$ - film, którego główni bohaterowie zostają zmuszeni do odtworzenia przed kamerą swej pijackiej kłótni, co dzięki audiowizualnemu zapisowi ma w przyszłości zapobiec podobnym incydentom. Wyjatkowa wartość "Rekonstrukcji” opiera się na dogłębnej analizie możliwości kina jako medium zdolnego do rejestrowania życia (uczciwymi bądź nieuczciwymi środkami) w celu prowokowania określonych reakcji i wmuszania określonych postaw. Refleksywność nie jest tu narcystycznym czy egzotycznym trikiem, ale metoda służaca odsłonięciu niewygodnych prawd $^{24}$. Owym niewygodnym prawdom - tym razem związanym z historią Rumunii XX w. - Jude przygląda się w Nie obchodzi mnie... swoim piątym pełnometrażowym i fikcjonalnym dziele, wyraźnie odchodząc od estetyki symptomatycznej dla nowego kina rumuńskiego.

Główną bohaterką Nie obchodzi mnie... jest Mariana Marin ${ }^{25}$, reżyserka teatralna, która przygotowuje się do wystawienia rekonstrukcji na placu Rewolucji w centrum Bukaresztu. Jej przedstawienie ma dotyczyć zdobycia Odessy przez armię rumuńską w 1941 r. Ów podbój zakończył się masakrą Żydów - jedną z wielu, w które było zaangażowane wojsko kierowane przez ówczesnego premiera kraju Iona Antonescu ${ }^{26}$. Sama rekonstrukcja zostaje zaprezentowana w wieńczącej całość niespełna półgodzinnej sekwencji, natomiast przez zdecydowaną większość filmu obserwujemy zmagania Mariany z realizacją: długie sceny ukazujące badania historyczne, pracę ze statystami ( $\mathrm{z}$ którymi bohaterka niejednokrotnie będzie dyskutować o ich wątpliwościach dotyczących wymowy spektaklu), przygotowania 
oprawy dźwiękowej i wizualnej, wreszcie sprzeczki z Constantinem Movila urzędnikiem miejskim reprezentującym odmienne poglądy na temat historii i zaangażowania strony rumuńskiej w Holocaust. Dzieje kraju są w centrum zainteresowania - zarówno bohaterki, jak i reżysera. Dość powiedzieć, że wątek romansu ze starszym mężczyzną z którym Mariana prawdopodobnie jest $\mathrm{w}$ ciąży, choć początkowo wydaje się znaczący, szybko zostaje urwany, a gest ten można uznać za dowód zmiany wektora zainteresowania Judego. Jeszcze przed kilkoma laty Şerban Pavlu, stały współpracownik rumuńskiego reżysera, wcielał się w główne role ojców i byłych mężów (kreacje w Alexandrze i we Wszystkich w naszej rodzinie), teraz zaś grana przez niego postać jest związana z wątkiem na tyle drugorzędnym, że reżyser nie kwapił się, by doprowadzić go do jakiejkolwiek konkluzji. Marianę bowiem interesuje przede wszystkim historia Rumunii - to nie sprawy uczuciowe, ale prace nad projektem są dla niej priorytetem.

Nie obchodzi mnie... można potraktować jako długą debatę o najnowszych dziejach państwa rumuńskiego, nad którymi pochyla się Mariana, postać niewątpliwie pełniąca funkcję porte-parole Judego (choć ten podkreśla, by nie szukać paralel pomiędzy ich biografiami ${ }^{27}$ ). Nadrzędnym celem reżyserki jest przygotowanie widowiska nie tyle artystycznie wysmakowanego, ile wyraźnie zachęcającego odbiorcę do zadawania pytań o współodpowiedzialność Rumunii za Holocaust oraz kreowanie nastrojów antysemickich w czasach II wojny światowej. Artystka dąży do odkłamania historii i przypomnienia o współpracy marszałka Antonescu z Hitlerem. Nie bez powodu rumuński przywódca jest dla Mariany postacią centralną - już w 1993 r. na łamach amerykańskiego dziennika pisano o niepokojących próbach zrehabilitowania działań Antonescu, któremu w Rumunii stawiano pomniki ${ }^{28}$, a jak się miało okazać, w ciągu kolejnych dekad sytuacja nie uległa znaczącej zmianie ${ }^{29}$. Stąd też decyzja Judego, by w Nie obchodzi mnie... zacytować obszerny fragment filmu Nicolaescu, wspomnianego reżysera superprodukcji historycznych, który w 1994 r. zrealizował Zwierciadło (Oglinda) - hagiograficzny portret Antonescu, prezentujący go jako niezłomnego przywódcę dopraszającego się o karę śmierci w trakcie procesu sądowego ${ }^{30}$. Rewizja tego wizerunku jest naczelnym celem Mariany/Judego - wskazuje na to wypowiedź Antonescu, której fragment posłużył za tytuł filmu. Słowa o barbarzyńcach premier miał wypowiedzieć 8 lipca 1941 r., kiedy to zwrócił swoim podwładnym uwagę, by nie bali się użyć broni palnej przeciwko Żydom i „elementowi ukraińskiemu” ${ }^{31}$. Co interesujące, wypowiedź ta jest przywołana jeszcze w trakcie prób przez aktora, który w rekonstrukcji wciela się w marszałka Antonescu, natomiast nie słychać jej w czasie przedstawienia wieńczącego film. Ponowne przytoczenie tych słów nie okazało się konieczne, wszak priorytetem twórców jest, by nade wszystko dotarły one do widzów oglądających film.

Choć podczas akcji nikt tego nie komentuje, to można uznać, że miejsce, gdzie ma być zaprezentowane przedstawienie Mariany, nie zostało wybrane przypadkowo. Z placem Rewolucji wiążą się bowiem istotne dla Rumunii wydarzenia - to tutaj w grudniu 1989 r. odbył się masowy protest przeciw rządom Nicolae Ceaușescu, który wygłaszał swoje ostatnie publiczne przemówienie. Wyraźnie wyrażona przez mieszkańców dezaprobata wobec dyktatury kontrastuje z aplauzem, z jakim ukazana w filmie Judego publiczność przedstawienia Mariany przyjmuje zachowanie i politykę Antonescu. Tym samym autor Aferim! uwypukla przekaz 
swojego filmu, w ramach którego ujęto nie tylko przygotowania fikcyjnej rekonstrukcji, samą rekonstrukcję, ale także reakcję widowni na widok zainscenizowanej rzezi. Ostatnie długie ujęcie przedstawiające kukły wisielców jest w tym kontekście aż nadto dosadnym odautorskim komentarzem.

\section{Historie (z) archiwów}

Kolejny fabularny projekt ${ }^{32}$ Judego pod względem narracji niewątpliwie różni się od dzieła z 2018 r. Abstrahując jednak od kwestii języka filmowego, Drukowanymi literami również sytuuje w centrum narracji wydarzenia z przeszłości państwa rumuńskiego. To poniekąd sequel poprzedniego filmu, w którym urzędnik miasta sugerował Marianie, by jej następne przedstawienie dotyczyło okresu komunizmu powszechnie wzbudzającego jednoznacznie negatywne emocje, a nie stawiające Rumunów w niekorzystnym świetle wydarzenia II wojny światowej ${ }^{33}$. Drukowanymi literami można interpretować jako spełnienie tych obietnic.

Akcja tego dzieła rozgrywa się nie wokół politycznego lidera, ale zapomnianego dysydenta, którego bohaterski czyn nie został zdaniem Judego należycie doceniony i opisany przez historyków ${ }^{34}$. Tą postacią jest Mugur Călinescu, który na początku lat 80., jeszcze jako osoba niepełnoletnia, na murach budynku urzędowego w Botoszanach wypisał kredą serię antykomunistycznych haseł. Ów gest był zainspirowany - jak sam potem zeznawał - wydarzeniami Sierpnia '80 w Polsce, o których słyszał w Radiu Wolna Europa. Securitate (tajne służby w Rumunii) poszukiwało Călinescu przez kilkadziesiąt dni, zorganizowało rozległą sieć współpracowników (wśród nich znaleźli się także nieangażujący się politycznie obywatele) do bacznego obserwowania miejsca zamieszkania autora napisów. Po schwytaniu Călinescu miesiącami trwały przedłużające się przesłuchania (nie tylko sprawcy, ale też jego rodziny, kolegów z klasy, nauczycieli), w wyniku których nastolatek miał zmienić swój stosunek do władzy i wartości socjalistycznych. Śmierć Călinescu w 1985 r. (w wieku 19 lat) do dziś jest owiana tajemnicą - nie do końca wiadomo, czy była ona skutkiem rozwijającej się choroby, czy jak twierdzą niektórzy (w tym matka buntownika), stopniowego podtruwania podejrzanego młodzieńca w trakcie kolejnych spotkań z reprezentantami Securitate.

Film Judego - drobiazgowo relacjonujący etapy śledztwa rumuńskich służb - jest adaptacją sztuki Gianiny Cărbunariu. Dramaturżka dokonała analizy akt sprawy Călinescu i na ich podstawie przygotowała tekst, którego dialogi są cytatami z oficjalnej dokumentacji ${ }^{35}$. Na potrzeby filmu autor Aferim! zatrudnił aktorów - wśród nich Şerbana Pavlu oraz Ioanę Iacob, odtwórczynię głównej roli w Nie obchodzi mnie... - którzy wcielili się w postacie wspomniane w tekstach archiwalnych. Krótkie monologi i dialogi są jednak wypowiadane przez nich w stronę kamery (z wyjątkiem scen, kiedy podczas rozmowy aktorzy patrzą na siebie), zatem przy zastosowaniu nieczęstych w nowym kinie rumuńskim chwytów dystansacyjnych. Co więcej, aktorzy występują na tle minimalistycznej scenografii, mającej za sprawą niezbyt rozbudowanych elementów dekoracyjnych wskazywać, gdzie akurat rozgrywa się dana scena czy też kto wypowiada fragment tekstu.

Sceny, w których widzimy aktorów, zostały uzupełnione materiałami audiowizualnymi odnalezionymi w archiwach narodowej telewizji. Nie pełnią one 

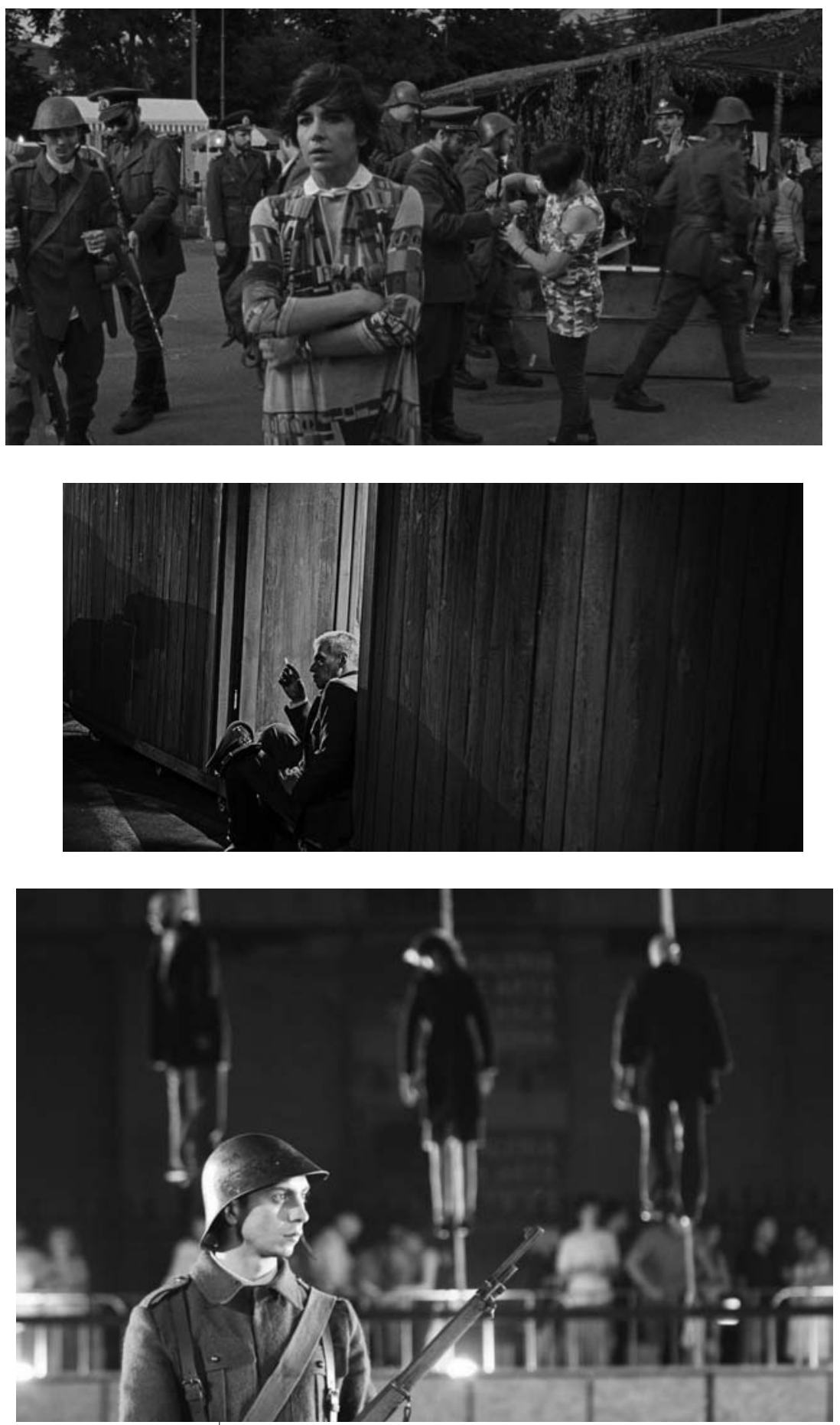

Nie obchodzi mnie, czy przejdziemy do historii jako barbarzyńcy, reż. Radu Jude (2018) 
funkcji (a przynajmniej taki był zamysł twórcy) komentarza wobec sekwencji aktorskich, odsłaniających kulisy wątku Călinescu. Są to fragmenty programów telewizyjnych o niekiedy zupełnie zaskakującej tematyce. Dość powiedzieć, że pośród zacytowanych obrazów znalazły się między innymi: materiał o mężczyźnie zdającym sprawę ze swego uwielbienia dla ćwiczeń fizycznych, sceny z reportażu o ludziach nagminnie używających klaksonów czy głośnym trzepaniu dywanów, fragmenty filmu edukacyjnego (o rzeźbie przedstawiającej myśliciela) i muzycznego (prezentującego występ zespołu ludowego), a także sekwencja zarejestrowanej opery o tematyce historycznej. Warto dodać, o czym Drukowanymi literami nie informuje, że przywołane fragmenty z telewizyjnego archiwum widzowie w Rumunii mogli zobaczyć w telewizji mniej więcej wtedy, gdy sprawa Călinescu była w toku ${ }^{36}$, co każe nam zestawić ze sobą oficjalną narrację - jaką reprezentuje $\mathrm{w}$ tym wypadku telewizja państwowa $-\mathrm{z}$ historia, której nagłośnienia unikano w dyskursie publicznym. Przyjęcie takiego sposobu opowiadania sprawia, że film operuje kontrastami - chodzi tu o rzucające się w oczy różnice pomiędzy tym, co było usankcjonowane i możliwe do powszechnego rozpowszechniania, a tym, co znalazło się w sferze tabu. Dla autora Aferim! równie istotne jest nie tylko to, co jest opowiadane, ale także jak jest opowiadane, co summa summarum czyni z Drukowanymi literami utwór na swój sposób refleksywny, skoncentrowany na warstwie metatekstowej. To z kolei łączy go z Nie obchodzi mnie... - oba filmy wyróżniają się bowiem zarówno zaangażowaną treścią jak i autotematyczną formą.

\section{Brechtowskie narracje}

Mimo estetyczno-narracyjnych różnic zarówno w Nie obchodzi mnie... jak i w Drukowanymi literami zostają rozwinięte wątki historiozoficzne. W obu Jude, niejako kontynuując tropy z Aferim!, zastanawia się nad tym, w jaki sposób historia może nam pomóc zrozumieć współczesność. Wyraźnie zarysowana perspektywa krytyczna uwydatnia - mniej lub bardziej intencjonalną - dydaktyczną wymowę tych utworów, co z kolei zbliża je do Brechtowskich Lehrstücke, takich dzieł, w których zwrócenie uwagi na grę aktorską pozwala na zachowanie odpowiedniego dystansu względem opisywanych w tekście zdarzeń i przyjęcie postawy analitycznej. Nie obchodzi mnie... oraz Drukowanymi literami pozostają pod tym względem odmienne. Są niewątpliwie brechtowskie, ale eksponują to podglebie przy wykorzystaniu innych środków z instrumentarium charakterystycznego dla filmowej metarefleksji. Odczytywane przez ten pryzmat, stają się tekstami rozwijającymi poetykę kinowego modernizmu, opisanego swego czasu przez Andrása Bálinta Kovácsa w studium o europejskim kinie arthouse'owym lat $1950-1980^{37}$.

Wpływ Brechta i jego teorii na analizowane utwory jest nie tylko ewidentny, ale też podkreślany przez samego reżysera ${ }^{38}$. Warto zaznaczyć, że niemiecki dramaturg tworzył formułę teatru epicko-dialektycznego ${ }^{39}$ (opracowywaną niespełna sto lat temu), wychodząc z założenia, że nowe sposoby wypowiedzi mogą pogłębić analizy rzeczywistości w stopniu nieporównywalnie większym, aniżeli ma to miejsce w utworze realistycznym. Dzięki zastosowaniu tak zwanych efektów obcości perspektywa widza diametralnie się zmienia: bierne przyglądanie się sce- 
nicznym działaniom ustępuje przyjęciu postawy krytycznego współuczestnika. Kierowane do aktorów rady (Pokażcie, że pokazujecie! ${ }^{40}$ ) miały w konsekwencji doprowadzić do aktywizacji odbiorcy zdającego sobie sprawę, że oglądany przezeń tekst kultury nie jest sentymentalny czy moralistyczny, lecz że ukazuje sentymentalność i morał ${ }^{41}$.

Inspiracje Brechtowską myślą w Nie obchodzi mnie... potwierdza już druga scena filmu. Na ekranie widzimy stojącą w przestrzeni muzealnej Ioanę Iacob, odtwórczynię roli Mariany, nie tylko zwracającą się do kamery, ale też przedstawiającą się z imienia i nazwiska oraz zaznaczająca, że będzie w tym filmie grać Marianę - reżyserkę, z którą jak sama mówi, niewiele ją łączy ${ }^{42}$. Iacob wymienia także nazwiska innych aktorów, a wyliczanie to przerywa asystentka informująca o przybyciu kandydatów do odegrania scen z rekonstrukcji. Udanego filmu! - mówi w kierunku kamery Iacob, która (w ramach tego samego długiego ujęcia) wchodząc do drugiej sali, zaczyna grać Marianę i prosi starszych naturszczyków, by pokazali próbkę swoich aktorskich umiejętności.

Również w kolejnych sekwencjach Nie obchodzi mnie... postaciom zdarza się zerkać w kierunku odbiorców, jak choćby wtedy, gdy Traian, asystent Mariany i odtwórca roli Antonescu w rekonstrukcji, zastanawiając się nad przywołaniem mowy rumuńskiego dyktatora, zaczyna ją cytować, patrząc nie na reżyserkę, lecz w stronę kamery. Podobny charakter mają sceny, w których znajdująca się w centrum kadru Mariana czyta na głos obszerne fragmenty książek. Trudno w tym wypadku nie zwrócić uwagi na czas trwania ujęć - w pierwszej tego rodzaju scenie statyczna kamera przygląda się lekturze bohaterki przez niespełna pięć minut.

Na innej zasadzie ów chwyt funkcjonuje w Drukowanymi literami, gdzie aktorzy w niemal wszystkich scenach zwróceni są frontem do odbiorców filmu, bez emocji cytując kolejne wypowiedzi z dokumentów o Călinescu. Sposób zaprezentowania losów tej postaci - a także jej bliskich i pracowników Securitate - jest szczególnie znamienny, zwłaszcza w kontekście decyzji Judego, który celowo zrezygnował z poetyki realistycznego filmu traktującego o rzeczywistości Rumunii lat 80. na rzecz chłodnej prezentacji, wyliczenia faktów i minimalistycznej scenografii. Jak gdyby, nawiązując do słów Brechta, zależało mu na ukazaniu samego morału, a nie na moralizowaniu. Opisując kulisy swoich artystycznych wyborów, reżyser Aferim! mówił tak: Uważam, że emocje moga ujawniać się na różne sposoby. W moim przekonaniu im bardziej złożona jest dana emocja, tym większa jest jej wartość. (...) jako odbiorca musisz wykonać pewna prace, by dotrzeć do emocji. To samo tyczy się kina. Nie chodzi mi o to, by ogladanie filmu przypominato przygladanie się prognozie pogody czy czegoś w tym rodzaju. Jestem (...) za złożonymi emocjami i (...) suma przemyśleñ ${ }^{43}$.

W swoich ostatnich, wyprodukowanych po Aferim! filmach Jude rozwija fabułę, opierając się na koncepcjach brechtowskich narracji. Chętnie ujawnia warsztat filmowy, podkreśla znaczenie pracy archiwalnej, nie tylko nie kryje faktu, że dana scena została zainscenizowana, ale wręcz eksponuje autotematyczną płaszczyznę utworu. To umożliwia mu nawiązanie więzi z odbiorcą podobnej do tej, do jakiej dążyli swego czasu Jean-Luc Godard (choćby w filmie 2 lub 3 rzeczy, które o niej wiem /2 ou 3 choses que je sais d'elle, 1968/ $/ 4$ ) czy tandem reżyserski Jean-Marie Straub Danièle Huillet (zob. Lekcje historii /Geschichtsunterricht, 1972/45). 

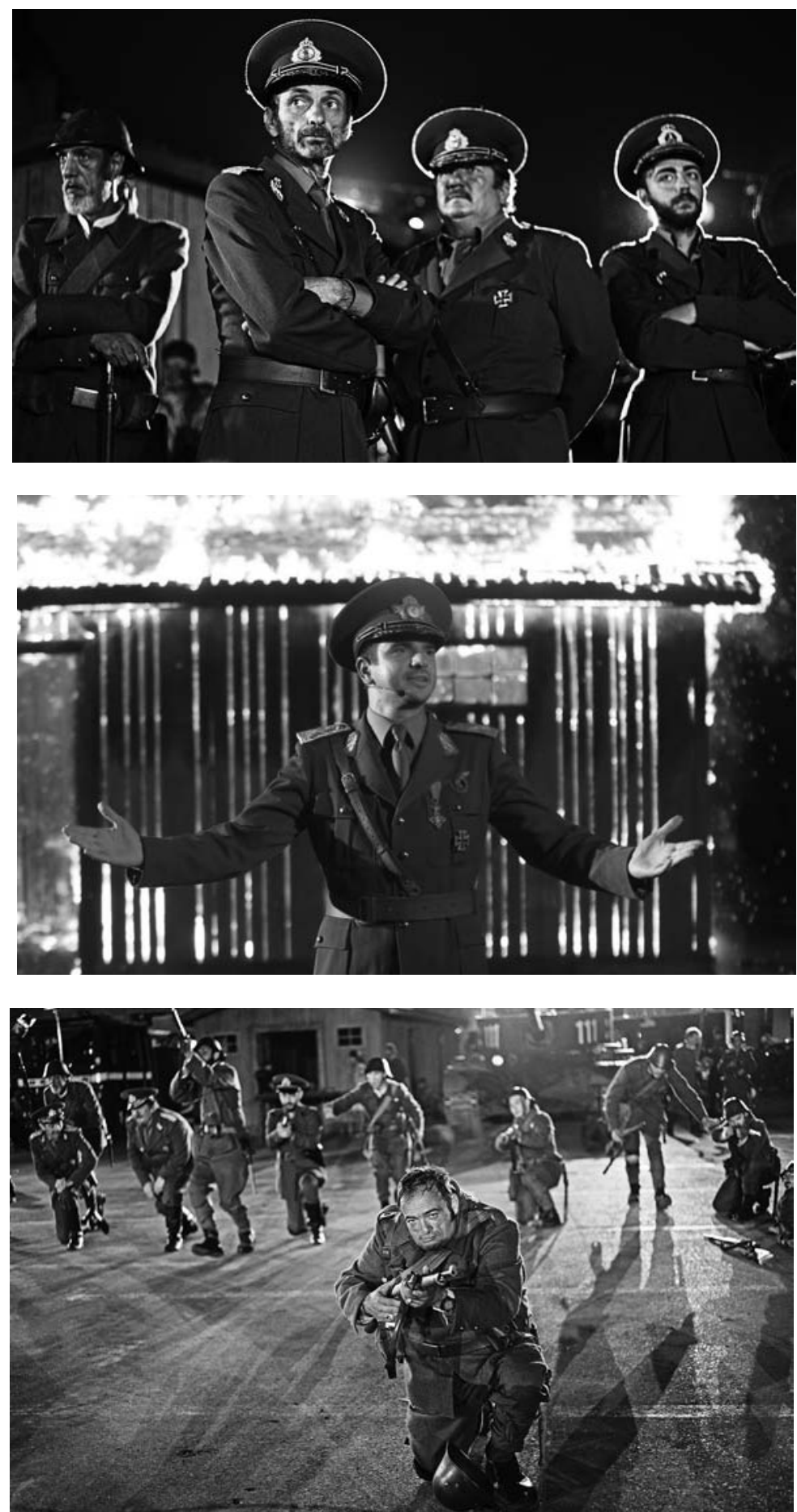

Nie obchodzi mnie, czy przejdziemy do historii jako barbarzyńcy, reż. Radu Jude (2018) 

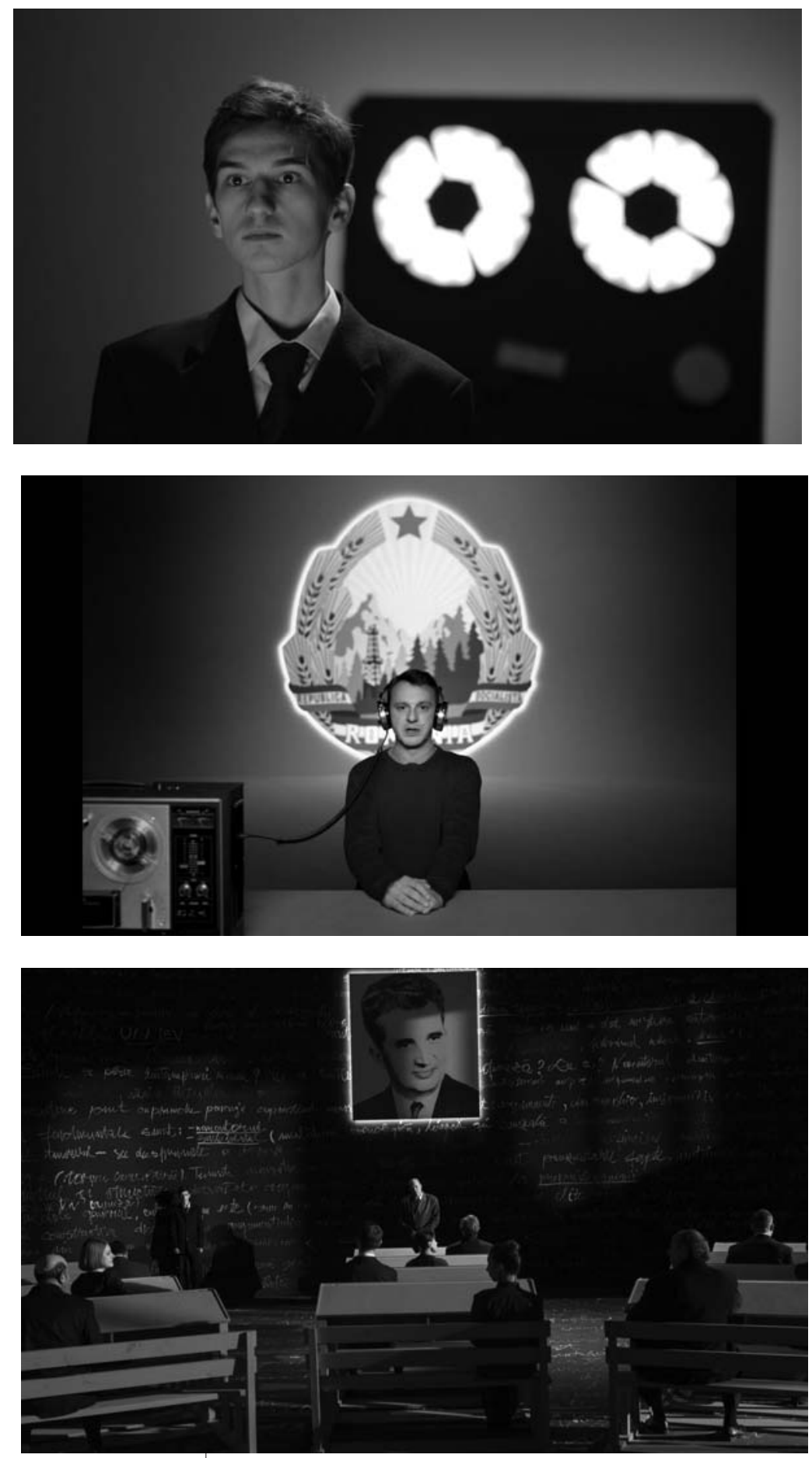

Drukoæanymi literami, reż. Radu Jude (2020) 
Niemałe znaczenie ma tu teatralizacja, o której w kontekście kina modernistycznego pisał Kovács. Charakteryzując europejskie arthouse'owe filmy trzydziestolecia 1950-1980, węgierski badacz dostrzegł u niektórych reżyserów znamienną tendencję do sięgania w swych utworach po język teatru ${ }^{46}$. Przejawia się to z jednej strony stroniącym od realizmu psychologicznego nienaturalnym aktorstwem, a z drugiej sztucznością scenografii i zastosowaniem zbyt wyrazistego oświetlenia ${ }^{47}$. Silna moda na teatralność - pisał Kovács - pojawiła się w okresie modernizmu politycznego, który wynikat ze wzmożonej świadomości politycznej zaczerpniętej z Brechtowskiego teatru politycznego ${ }^{48}$. Choć autor Screening Modernism pisze o kinie ubiegłego wieku, to charakteryzowana przez niego poetyka jest dostrzegalna także $\mathrm{w}$ dziełach realizowanych, jak się okazuje, współcześnie. Co jednocześnie pozwala nam skonstatować, że Jude nie tylko inspiruje się stylistyką i narracją filmów z opisywanego przez Kovácsa trzydziestolecia, ale także stara się aktualizować i rozwijać elementy poetyki kina artystycznego tamtej epoki.

Odniesienia do wspomnianej tradycji nie są u Judego bez znaczenia, chodzi bowiem nie tyle o nawiązanie do klasyki filmu, ile przede wszystkim o ciąłe poszukiwanie odpowiednich środków wyrazu, mogących uwypuklić znaczenie tematów poruszanych przez twórcę Drukowanymi literami, które - jak zaznaczyliśmy - nie zostały podjęte przez innych rumuńskich reżyserów. Pascal Bonitzer pisał, że stosowany w kinie modernistycznym efekt teatru można uznać za symptom kryzysu "mise-en-scène", organizacji przestrzennej lub jej ideologicznych podstaw ${ }^{49}$. Idąc tym tropem, trzeba by uznać, że poetyka realizmu - do której tak chętnie odwołują się reżyserzy reprezentujący nowe kino Rumunii, a także jego komentatorzy przestaje wystarczać. Opisywane filmy Judego mogą więc być sygnałem wyczerpania się pewnego typu narracji.

\section{W stronę kina metahistorycznego}

Nie obchodzi mnie... i Drukowanymi literami są brechtowskimi dziełami także w tym sensie, że stawiają pytania o historię i jej wpływ na współczesność. Oba wyraźnie zaznaczają tę perspektywę - analiza dziejów nie może się obyć bez znajomości tego, jak kraj wygląda dziś. I odwrotnie - dokładne rozpoznanie przeszłości pozwala nam lepiej zrozumieć teraźniejszośćc ${ }^{50}$. Warto w tym kontekście odwołać się do rozróżnienia autorstwa Angelosa Koutsourakisa, który pisał o trzech rodzajach utworów wyraźnie inspirowanych Brechtowską myślą ${ }^{51}$. Do jednego z nich należą filmy kładące nacisk na re-wizję historii ${ }^{52}$. Badacz, odnosząc się do dzieł realizowanych między innymi przez Miklósa Jancsó czy Theo Angelopoulosa, zaznaczał, że innowacyjność ich filmów nade wszystko opiera się na pytającej postawie wobec historii, co zostaje uwidocznione także na poziomie formalnym. Ich epistemologiczna refleksyjność, jak pisze Koutsourakis, zobowiąuje do ukazania śladów historycznych sprzeczności w teraźniejszości ${ }^{53}$. Ewentualne formalne eksperymenty w zakresie narracji, co istotne, nie służą w tego typu filmach wyłącznie estetyzacji. Przede wszystkim mają one zaprosić widzów do przewartościowania dialektyki historii i umieszczenia jej w teraźniejszości ${ }^{54}$.

Nie mniej istotne rozróżnienie zaproponował Robert Rosenstone, który pisał o rozmaitych sposobach podejścia do tematów historycznych w kinie. Wedle badacza reżyserzy mogą koncentrować się na wizji historii (co miałoby polegać na 

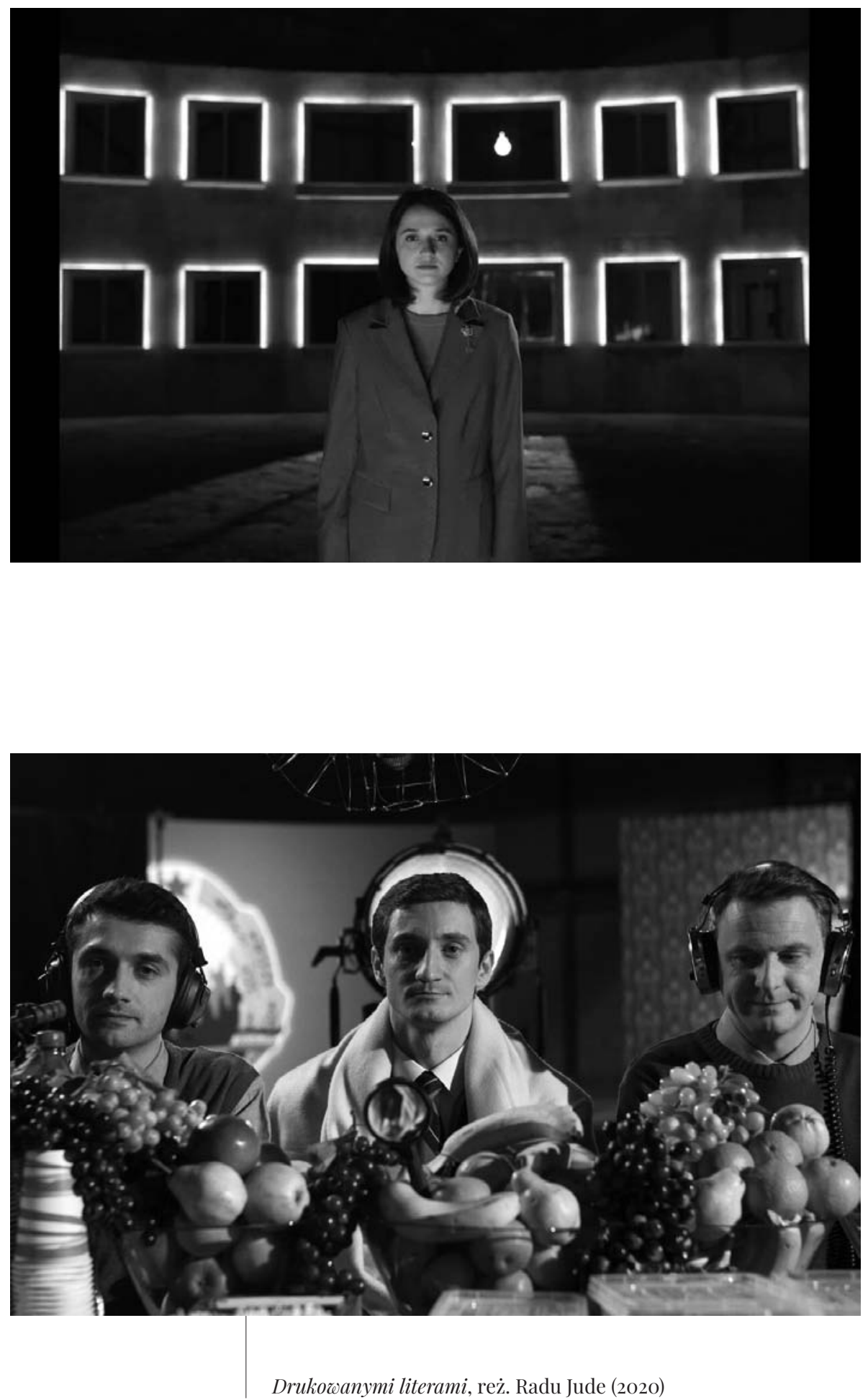
dramatyzacji wydarzeń, prezentowaniu postaci, z którymi widz może się identyfikować, wreszcie zapewnieniu odbiorcom takich emocji, jakie mogli przeżywać portretowani bohaterowie), jej kwestionowaniu (co wiązałoby się z propozycją interpretacji stojącej w sprzeczności z dotychczasową wiedzą i mogącej podważyć utarte poglądy na temat osób, wydarzeń czy tematów) oraz jej rewizji (co polegałoby na pokazywaniu przeszłości przy zastosowaniu niekonwencjonalnych środków wyrazu, naruszających niekiedy klasyczne sposoby opowiadania o przeszłości, i/lub mieszaniu narracji charakterystycznych dla danych gatunków filmowych, a wszystko po to, by uczynić "znajome nieznanym" i nakłonić widownię do reinterpretacji uznanych faktów) ${ }^{55}$. Choć granice pomiędzy drugim a trzecim typem filmów wydają się dość płynne, to nie ulega wątpliwości, że Nie obchodzi mnie... i Drukowanymi literami pozostają utworami zachęcającymi widza do przyjęcia perspektywy analitycznej, dążącymi do opowiedzenia o historii w nieklasyczny sposób oraz zwrócenia uwagi na konwencjonalność większości produkcji historycznych.

Oglądając dzieła Judego, odbiorca nie koncentruje się na wiarygodności scenograficznej (na którą kładzie się tak duży nacisk w przypadku kina historycznego). Trudno bowiem wyobrazić sobie bardziej umowne dekoracje aniżeli te widoczne w Drukowanymi literami ${ }^{56}$. Co więcej, przyjęty przez realizatorów sposób opowiadania nie pozwala dokładnie określić, kiedy rozgrywa się akcja filmu. Bo choć nie mamy wątpliwości, że jest mowa o latach 80. XX w. (na ekranie co jakiś czas pojawiają się informujące o tym plansze), to zarówno eksplicytna teatralizacja - uwydatniona scenograficznym minimalizmem i brechtowską grą aktorską - jak i cytaty z programów telewizyjnych skutecznie zwracają uwagę na refleksywny sposób opowiadania i tym samym nie pozwalają z pełnym przekonaniem stwierdzić, gdzie i kiedy dzieje się to, co właśnie oglądamy.

Nie obchodzi mnie... nie rodzi podobnych wątpliwości - to film portretujący bohaterów żyjących we współczesnej Rumunii i nawet jeśli na ekranie często oglądamy materiały archiwalne, to wiemy, że winniśmy na nie patrzeć tak jak bohaterowie filmu, czyli z perspektywy kogoś żyjącego w drugiej dekadzie XXI w. Wiedza o sposobach dotychczasowego problematyzowania dziejów kraju w rozmaitych tekstach (kultury) jest tu kluczowa. Akcentują to także sceny prezentujące proces pracy nad przedstawieniem czy sekwencje rozbudowanych dialogów między Marianą a Constantinem Movila, debatującymi nad sensownością takiej czy innej interpretacji dziejów Rumunii. Różnica zdań między podkreślającą swoje lewicowe poglądy, bezkompromisową artystką a kompetentnym, acz wyraźnie dążącym do storpedowania jej ambitnych planów urzędnikiem ${ }^{57}$ wzbogaca dialektyczny charakter Nie obchodzi mnie... filmu akcentującego przeciwieństwa i zestawiającego postaci reprezentujące odmienne punkty widzenia.

Wysuwając problem wyboru narracji o danym okresie historycznym na pierwszy plan, Jude sygnalizuje, że przyjmuje perspektywę, w której refleksja nad dziejami i ich wpływem na współczesność odgrywa ważniejszą rolę aniżeli inscenizowanie kluczowych wydarzeń z przeszłości. Choć w Nie obchodzi mnie... sekwencja z rekonstrukcją pełni istotną funkcję, to Judego, jak się wydaje, bardziej fascynuje proces jej powstawania, dyskusje nad jej charakterem, wreszcie jej recepcja (stąd częste ujęcia ukazujące publiczność żywo reagującą na wydarzenia sceniczne). Z kolei odbiór Drukowanymi literami niewątpliwie determinuje aktorstwo ${ }^{58}$ - zapre- 
zentowane na ekranie postaci nawet na moment nie pozwalają nam zapomnieć, że są jedynie osobami nie tyle odtwarzającymi dobrane wcześniej role, ile beznamiętnie podającymi kolejne linie dialogowe zaczerpnięte z oficjalnych dokumentów.

Brechtowski charakter obu dzieł uwypuklają też refleksywne chwyty, nieustannie podkreślające polityczne zaangażowanie filmów. Za takie można uznać sekwencje typu found footage. Nie obchodzi mnie... inicjuje zresztą znamienna w tym kontekście scena. W kadrze widać ekran monitora, na którym jest wyświetlany niemy fragment antysowieckiego dokumentu ukazującego żołnierzy „wyzwalających" Odessę - Jude już w tym momencie odsłania kulisy podszytej kłamstwem oficjalnej narracji i niejako ustanawia nadrzędny cel swojej opowieści, jakim jest polemika z określonym dyskursem. Podobną funkcję pełnią archiwa przywołane wDrukowanymi literami, które nie korespondują z wagą głównego tematu dzieła. Zestawiając ze sobą dwie płaszczyzny narracyjne, Jude nader dosadnie akcentuje kontrast pomiędzy dwiema historiami z lat 80. - tą usypiającą społeczeństwo (czyli telewizyjną) i tą związaną z młodym buntownikiem dążącym do obudzenia swoich rodaków.

Obecne w obu dziełach wyraźne dążenie do rekontekstualizacji zrealizowanych wcześniej materiałów audiowizualnych pozwala dokonać ich ponownego odczytania, także dzięki obejrzeniu ich przez pryzmat zaproponowany przez autora $^{59}$. Found footage służy tym samym nie tyle rozbudowaniu awangardowej poetyki opisywanych utworów, ile nakreśleniu perspektywy zainteresowanego historią twórcy ${ }^{60}$, któremu zależy na zdekonstruowaniu dominującej w dyskursie ideologii ${ }^{61}$. I choć rumuński reżyser nie eksperymentuje z fakturą obrazów (co jest jedną z praktyk artystów realizujących filmy typu found footage ${ }^{62}$ ), to często w sposób niespodziewany ucina dany fragment filmu, by wrócić do głównego wątku dzieła, choćby historii życia Călinescu. Tym samym jeszcze wyraźniej uwydatnia zaangażowane podglebie swojego filmu.

Refleksywność Nie obchodzi mnie... i Drukowanymi literami jest podporządkowana przekazowi politycznemu, co niejako koresponduje z poetyką utworów, którym przyglądał się w swoim studium Kovács ${ }^{63}$. Jude odsłania kulisy nie tylko rekonstrukcji czy polityki, ale także swojego warsztatu, co widać zwłaszcza w Nie obchodzi mnie... w którym Mariana przywołuje wiele nazwisk inspirujących ją historyków (Jean Ancel, Dennis Deletant, Raul Hilberg), czyta fragmenty książek, między innymi Izaaka Babla (w trakcie tej lektury jest widoczna z prawej strony kadru okładka anglojęzycznego wydania My z Jedwabnego Anny Bikont ${ }^{64}$ ), komentuje oglądane fragmenty Zwierciadła Nicolaescu, dzieciom przygotowującym się do ról w przedstawieniu pokazuje okładkę A Child at Gunpoint Richarda Raskina, na której widać słynne zdjęcie chłopca z getta warszawskiego, a samej rekonstrukcji nadaje podniosły tytuł Narodziny narodu, co odsyła do problematycznego arcydzieła D. W. Griffitha. Nie sposób nie odczytać tych licznych odniesień jako swoistych przypisów do audiowizualnego studium nad historią. Uwidocznienie ramy ekranu, na którym jest wyświetlany fragment dokumentu w pierwszych minutach Nie obchodzi mnie... okazuje się więc szczególnym odautorskim gestem reżysera stale podkreślającego intertekstualność swych ostatnich filmów, co w dużym stopniu koresponduje z licznymi inspiracjami lekturowymi, o których Jude mówi w niemal każdym wywiadzie. 
Pozostaje pytanie, na ile rewizjonizm Nie obchodzi mnie... i Drukowanymi literami pozwala uznać je za symboliczne otwarcie kolejnego rozdziału nowego kina rumuńskiego. Daleki jestem od jednoznacznych konstatacji wskazujących, że mamy do czynienia ze zmierzchem dominacji filmów operujących szeroko pojętym minimalizmem ${ }^{65}$. Nie zmienia to jednak faktu, że odczytanie powyższych tytułów na tle dotychczasowych tendencji tamtejszej kinematografii nie jest bezzasadne. Opisane dzieła rozwijają poetykę autotematyzmu, tak istotną dla filmowców kina Rumunii XX w.: Luciana Pintiliego (wspomniana Rekonstrukcja), Mircei Daneliuca (reżysera Próby mikrofonu /Probă de microfon, 1980/), Iosifa Demiana (twórcy Łez dziewczyny /O lacrimă de fata, 1980/) czy Alexandru Tatosa (autora Sekwencji /Secvențe, 1982/). O ich filmach pisała Dana Duma, zestawiając je z późniejszymi dziełami, w których komponenty refleksywne także odgrywały ważną rolę. Zdaniem badaczki, takie filmy jak Rekonstrukcja czy Próba mikrofonu traktują o mocy kamery jako narzędzia do manipulowania lub prowadzenia swoistego śledztwa, czego nie akcentowały utwory wyprodukowane w następnym stuleciu (jak 12:08 na wschód od Bukaresztu). Współcześni autorzy, konstatowała, w przeciwieństwie do reżyserów działających w latach 70. i 80., nie muszą się martwić o jakiekolwiek implikacje polityczne ${ }^{66}$. Z kolei Jude, rozwijając poetykę modernizmu filmowego, wykorzystuje środki autotematyczne i brechtowską narrację, by w sposób krytyczny odnieść się do tych problemów, które dotychczas nie zostały wyczerpująco opisane w kinie rumuńskim. Wyraźna samozwrotność zrealizowanych przez niego filmów pozwala mu uwypuklić autorską perspektywę kogoś, kto zgłębia historię swojego kraju.

${ }^{1}$ Jude mówił o tym w wielu wywiadach. Zob.: G. Andrew, Lives Less Ordinary, „Sight \& Sound" 2016, t. 26, nr 6; H. Emmerzael, Reaching Into History: Radu Jude on "Uppercase Print" and "The Exit of the Trains", "Senses of Cinema" 2020, https://www.sensesofcinema.com/2020/conversations-with-filmmakers-across-theglobe/radu-jude/ (dostęp: 1.06.2021).

${ }^{2}$ Zob. więcej na temat literackich inspiracji Judego: D. Dąbrowska, Troche z Cervantesa, troche z Czechowa, rozmowa z Radu Jude, „,Kino” 2015, nr 11, s. 30-31.

${ }^{3}$ Podstawowymi opracowaniami zagadnienia pozostają trzy monografie nurtu: D. Nesta, Contemporary Romanian Cinema. The History of an Unexpected Miracle, Wallflower Press, London - New York 2013; D. Pop, Romanian New Wave Cinema. An Introduction, McFarland \& Company, Inc., Publishers, Jefferson, North Carolina 2014; The New Romanian Cinema, red. Ch. Stojanova, współprac. D. Duma, Edinburgh University Press, Edinburgh 2019.

${ }^{4}$ Zob. m.in.: M. Bartczak, W ogniu filmowej rewolucji, „Ekrany” 2011, nr 1-2, s. 29-33; S. Py- tel, Melancholia dnia codziennego: rumuńska nowa fala, "ArtPapier” 2015, nr 23 (287), http://artpapier.com/index.php?page $=$ artykul\&wydanie $=290 \&$ artykul=5268\&ka $\mathrm{t}=3$ (dostęp: 1.06.2021); R. Syska, (Re)konstruowanie pamięci o Rewolucji w nowym kinie rumuńskim, „Images” 2015, t. 17, nr 26, s. 5-14; do fenomenu rumuńskiego kina w kontekście jego reprezentacji na ważniejszych festiwalach filmowych odnosi się Marcin Adamczak we fragmencie swojej książki: Rumuńskie kino i polski handel zbożem, w: tegoż, Kapitały przemystu filmowego. Hollywood, Europa, Chiny, Wydawnictwo Naukowe PWN SA, Warszawa 2019.

${ }^{5}$ Zob. teksty, w których rumuńskie filmy są interpretowane przez podobny pryzmat: D. Nesta, Less is More: Puiu, Porumboiu, Muntean and the Impact of Romanian Film Minimalism, w: tejże, Contemporary Romanian Cinema... dz. cyt.; I. Trocan, Minimalism in New Romanian Cinema: Absent, Omnipresent or Misjudged?, w: The New Romanian Cinema... dz. cyt.; I. Uricaru, No Melo: Minimalism and Melodrama in the New Ro- 
manian Cinema, w: The New Romanian Cinema... dz. cyt.

${ }^{6}$ Do kilku rumuńskich filmów (choćby Policjanta, przymiotnika/Politist, adjectiv, reż. C. Porumboiu, 2009/ czy Aurory, reż. C. Puiu, 2010) jako dzieł reprezentujących slow cinema odwołuje się Rafał Syska, Filmowy neomodernizm, Wydawnictwo Avalon, Kraków 2014. Podobny klucz interpretacyjny w odniesieniu do Śmierci pana Lazarescu oraz 4 miesięcy, 3 tygodni i 2 dni (4 luni, 3 săptămâni şi 2 zile, reż. Cristian Mungiu, 2007) sugeruje Ira Jaffe (zob. rozdział Wait Time. "The Death of Mr. Lazarescu", "4 Months, 3 Weeks and 2 Days" and "Safe", w: tegoż, Slow Movies: Countering the Cinema of Action, Wallflower Press, London - New York 2014). Filmy Porumboiu przez pryzmat poetyki slow cinema ogląda także Marta Stańczyk (Corneliu Porumboiu $i$ antyfilm, w: tejże, Czas $w$ kinie. Doświadczenie temporalne w slow cinema, Wydawnictwo Uniwersytetu Jagiellońskiego, Kraków 2019.

${ }^{7}$ R. Syska, (Re)konstruowanie pamięci... dz. cyt., s. $12-13$.

${ }^{8}$ Tamże, s. 14.

9 Dyktatura się skończyła, towarzyszu Nicolae Ceaușescu! - mówi Tavi, główny bohater krótkometrażowej Alexandry (2006), do swojej byłej żony, kiedy ta za wszelką cenę dąży do przeorganizowania harmonogramu dnia, który mężczyzna ma spędzić ze swoją córką.

${ }^{10}$ Ciekawą interpretację proponuje jeden z monografistów historii kina rumuńskiego, odczytujący pierwsze dzieła Judego jako utwory o kryzysie męskości w społeczeństwie postsocjalistycznym. Zob. L. Strausz, Hesitant Histories on the Romanian Screen, Palgrave Macmillan, London 2017, s. 209-238.

${ }^{11}$ Zob. więcej na ten temat: P. Biliński, Rekonstrukcje. Kino Radu Judego, „Ekrany” 2020, nr 2 (54), s. 65-70.

${ }^{12}$ Ch. Stojanova, Authenticity in New Romanian Cinema: "Ethics and Aesthetics Are One", w: The New Romanian Cinema... dz. cyt., s. 123.

${ }^{13}$ M. Stelmach Socprzeboje. Wschodnioeuropejskie filmy z największa liczba widzów na rodzimych rynkach, „Ekrany” 2020, nr 4, s. 22.

${ }^{14} \mathrm{Ch}$. Stojanova, Historical Overview of Romanian Cinema, w: The New Romanian Cinema... dz. cyt., s. 261-263.

${ }^{15}$ Również Aferim!, jak wspomniano wcześniej, można potraktować jako dzieło dyskutujące z tradycją realizacji eskapistycznych filmów, które prezentowały historię w sposób zgodny z linią ideologiczną rządzącej partii i oficjalną narracją. Poprzez podjęcie tak niewygodnych tematów, jak choćby kwestia niewolnictwa,
Aferim! staje się utworem, którego premierę moglibyśmy uznać za próbę otwarcia nowego rozdziału rodzimej kinematografii. Zob. A. Vizitiu, Creating a National Identity in Film: The Historical and Mythological Past in Romanian Cinema, w: Romanian Cinema Inside Out: Insights On Film Culture, Industry and Politics - 1912 -2019, red. I. Trocan, Romanian Cultural Institute, Bucharest 2019, s. 143-146.

${ }^{16}$ Co skądinąd bywa także problematyzowane przez teoretyków. Zdaniem Moniki Woźniak, film historyczny jest przypadkiem szczególnie niewdzięcznym, zarówno dlatego, że bardzo trudno jest znaleźć zespót stałych cech charakteryzujacych wszystkie obrazy historyczne, jak też z racji ich stałego krzyżowania się z innymi gatunkami. Zob. M. Woźniak, Gatunek filmowy w przekładzie: historia na ekranie, w: A. Hołobut, M. Woźniak, Historia na ekranie. Gatunek filmowy a przektad audiowizualny, Wydawnictwo Uniwersytetu Jagiellońskiego, Kraków 2017, s. 71.

${ }^{17}$ Tamże.

${ }^{18}$ E. Durys, Film jako źródło wiedzy historycznej, Wydawnictwo Instytutu Nauki o Polityce, Warszawa 2019, s. 34.

${ }^{19}$ Durys odwołuje się choćby do filmu Smoleńsk (reż. A. Krauze, 2016), który co prawda powstał ponad pięć lat po wydarzeniach, o których opowiada, jednak bardziej skłonni bylibyśmy określać go mianem filmu politycznego. Zob. Tamże.

${ }^{20}$ Tamże, s. 36.

${ }^{21}$ W. Guynn, Przekształcanie historii w filmie, tłum. T. Rutkowska, K. Kosińska, „Kwartalnik Filmowy" 2010, nr 69, s. 13.

${ }^{22}$ Koresponduje to z myślą Pierre'a Sorlina, który uważa, że film historyczny przede wszystkim dostarcza informacji o współczesności. Teorię tę badacz rozwinął w często przywoływanej książce: P. Sorlin, The Film in History: Restaging the Past, Barnes \& Noble, Totowa, NJ 1980.

${ }^{23}$ W przygotowanym w 2008 r. zestawieniu najwybitniejszych filmów rumuńskich dzieło Pintiliego zajęło pierwsze miejsce, wyprzedzając Las powieszonych (Pădurea spânzuraților, reż. L. Ciulei, 1964) oraz Śmierć pana Lazarescu. Zob. I. Blaga, Cele mai bune 10 filme romanesti ale tuturor timpurilor, acum si in carte, "HotNews", https://www.hotnews.ro/stiri-film-7472317cele-mai-bune-10-filme-romanesti-ale-tuturortimpurilor-acum-carte.htm (dostęp: 1.06.2021).

${ }^{24}$ D. Duma, Self-reflexivity in New Romanian Cinema: A Method of Working, „Close Up. Film and Media Studies" 2018, t. 2, nr 2, s. 10.

${ }^{25}$ Nadanie bohaterce takiego imienia i nazwiska można uznać za hołd dla prawdziwej Mariany Marin - rumuńskiej poetki znanej ze swojej 
antyreżimowej postawy w latach 80. Zob. więcej na ten temat: L. Boyce, Karlovy Vary QEA: Radu Jude on Exploring Romanian AntiSemitism in New Film "Barbarians", ,Screen Daily" 2018, https://www.screendaily.com/karlovy-vary-qanda-radu-jude-on-exploring-romanian-anti-semitism-in-new-film-barbarians/5130557.article (dostęp: 1.06.2021).

${ }^{26}$ Szczegółowo o tym okresie pisali między innymi Dennis Deletant (Rumunia. Zapomniany sojusznik Hitlera, tłum. M. Baranowski, Bellona SA, Warszawa 2005) oraz Radu Ioanid (Holocaust in Romania. The Destruction of Jews and Gypsies Under the Antonescu Regime, 1940-1944, wstęp E. Wiesel, Ivan R. Dee, Inc., Chicago 2000).

${ }^{27}$ L. Boyce, dz. cyt.

${ }^{28}$ A. Codrescu, Fascism on a Pedestral, "The New York Times", https://www.nytimes.com/1993/12/07/opinion/fascism-on-a-pedestal.html (dostęp: 1.06.2021).

${ }^{29}$ Problem opisywał między innymi Dennis Deletant: Jednym z najbardziej zgubnych skutków epoki komunizmu był wypaczony obraz historii, który pozostawiła w spadku. Manipulowanie przeszłościa dla celów politycznych nie skończyło się wraz z upadkiem komunizmu. Sprawa Antonescu stała się po obaleniu Ceaușescu przede wszystkim zagadnieniem politycznym, a warstwa historyczna zeszła na dalszy plan. Zachwyt $i$ wyolbrzymianie jego zastug politycznych przy jednoczesnym umniejszaniu odpowiedzialności za śmierć ponad $250000 \dot{Z} y d o ́ w$ stanowią narzędzie propagandy w rękach tych, którzy odwotują się do patriotyzmu w imię ultranacjonalizmu przeciwko zarówno monarchii konstytucyjnej, jak i siłom demokratycznym. Zob. D. Deletant, dz. cyt., s. 393.

${ }^{30}$ Heroizacja zachowania Antonescu w Zwierciadle nie ulega większej wątpliwości - z zestawionych przez Deletanta świadectw wynika, że marszałek w trakcie procesu w $1946 \mathrm{r}$. usiłował zracjonalizować swoje działania, a jego prawnicy do końca zabiegali o ułaskawienie. Zob. tamże, s. 367-377.

${ }^{31}$ Nie okazujcie litości! Kto wie, kiedy będziemy znowu mieli swobodę działania w kwestii etnicznej czystki i narodowych reform. Możecie użyć karabinów maszynowych. Nie dbam o to, czy przejdziemy do historii jako barbarzyńcy. Imperium Romańskie popetnito... - tak brzmi polska wersja (tłumaczenie autorstwa Piotra Kotowskiego na zlecenie Aurora Films, polskiego dystrybutora filmu Judego). Słowa te - choć w nieco innym kształcie - zostają też zacytowane w jednej z książek historycznych. Zob. R. Ioanid, dz. cyt., s. 92.

${ }^{32}$ Choć, co warto zaznaczyć, w kwestii przyporządkowania rodzajowego mamy do czynienia z dziełem niełatwym do jednoznacznego sklasyfikowania. Niemniej Drukowanymi literami zawiera obszerne partie, w których aktorzy wcielają się w role postaci autentycznych, co różni ów film od innych ważnych dla Judego projektów - chociażby Martwego narodu (Țara moartă, 2017) czy Odjazdu pociagu ze stacji (Ieşirea trenurilor din gară, 2020) - będących esejami dokumentalnymi, obficie korzystającymi z poetyki found footage.

${ }^{33}$ Kilkakrotnie w Nie obchodzi mnie... można dostrzec, jaki jest stosunek mieszkańców - głównie postaci drugiego planu, które będą brać udział w rekonstrukcji - do Ceaușescu i komunizmu. Już w pierwszych scenach jedna z uczestniczek castingu nie bez ironii wspomina ostatnie chwile życia Eleny Petrescu. Z kolei $\mathrm{w}$ trakcie dobierania aktorów do ról wojskowych (Mariana do rekonstrukcji potrzebuje mężczyzn odtwarzających czerwonoarmistów, żołnierzy niemieckich oraz wojskowych Rumunii) jeden z zebranych zaznacza, że może grać kogokolwiek, byle nie bolszewika. Wreszcie trudno nie zwrócić uwagi na sekwencję rekonstrukcji, kiedy to zebrana na placu publiczność oklaskuje aktorów odgrywających wojsko niemieckie, zaś zjawiających się na arenie żołnierzy ZSRR wygwizduje, kierując w ich stronę obraźliwe okrzyki.

${ }^{34}$ C. Gray, Director Radu Jude Is Harnessing Old Propaganda to Celebrate Romania's Forgotten Dissident Heroes, "The Calvert Journal", https://www.calvertjournal.com/features/show /11664/radu-jude-uppercase-print-film-romania-hidden-histories (dostęp: 1.06.2021).

${ }^{35}$ Dokumentacja ta, jeśli wierzyć twórcom, nie jest specjalnie rozbudowana $-\mathrm{w}$ jednym $\mathrm{z}$ wywiadów na platformie YouTube rumuński reżyser pokazuje do kamery teczkę zawierającą kilkaset stron o Călinescu. https://www.youtube.com/watch?v=EXE5w8PdQOk (dostęp: 1.06.2021).

${ }^{36}$ Reżyser zaznaczał, że fragmenty pochodzące $\mathrm{z}$ archiwum telewizyjnego zostały na potrzeby filmu dobrane niemal przypadkowo, o ile udało się dzięki nim uzyskać odpowiedni rytm narracji i spełniały one kryterium jakościowe. $\mathrm{W}$ ich umiejscowieniu pomagały daty, które można było odczytać z akt sprawy Călinescu. Zob. rozmowa przeprowadzona przez Lucię Salas dla platformy Dafilms, https://www.facebook.com/DAFilmsCOM/videos/1178917536 38258/ (dostęp: 1.06.2021)

${ }^{37}$ A. B. Kovács, Screening Modernism: European Art Cinema, 1950-1980, The University of Chicago Press, Chicago 2007.

${ }^{38}$ Zob. L. Boyce, dz. cyt. W przywołanej rozmowie Jude podkreślał, że taki kształt narracji 
ma mu pomóc $\mathrm{w}$ zachowaniu szczerej relacji z odbiorcą. Mówił: Nie mogę zrekonstruować (...) całej masakry w Odessie z 1941 roku, ale przynajmniej mógłbym zaoferować pewne jej elementy, które moga skłonić nas do wspólnej refleksji i zastanowienia się nad tym, co się stało, (...) oraz co możemy odtąd z tym faktem zrobić.

${ }^{39}$ Opisaną przez Brechta po raz pierwszy w studium z 1930 r. Zob. B. Brecht, Uwagi do opery "Rozkwit i upadek miasta Mahagonny", tłum. E. Misiołek, w: tegoż, Dramaty. Tom 1, Państwowy Instytut Wydawniczy, Warszawa 1979.

${ }^{40}$ B. Brecht, Pokazywanie trzeba pokazać, w: tegoż, Wartość mosiądzu, wybór, układ i noty: W. Hecht, tłum. M. Kurecka, Wydawnictwa Artystyczne i Filmowe, Warszawa 1975, s. 215.

${ }^{41}$ B. Brecht, Uwagi do opery... dz. cyt., s. 321.

${ }^{42}$ Warto zatrzymać się przy tym fragmencie. Iacob zaznacza, że podobnie jak odgrywana przez nią postać, jest rdzenną Rumunką, która została ochrzczona w kraju; jednak wymieniając różnice między nimi, podkreśla, że w przeciwieństwie do niej Mariana jest ateistką. Słowa te zaskakują w kontekście sekwencji prezentującej rekonstrukcję. Tuż przed rozpoczęciem przedstawienia w kadrze na chwilę pojawia się zestresowana reżyserka, która wykonuje znak krzyża, co można uznać za świadome zacieranie granic między fikcją a rzeczywistością.

${ }^{43} \mathrm{H}$. Emmerzael, dz. cyt.

${ }^{44}$ Warto dodać, że początkowa scena Nie obchodzi mnie... w której Iacob zaznacza, że w tym filmie odtwarza postać fikcjonalną, jest wyraźnie zainspirowana przywołanym dziełem Godarda. Tu również od pierwszych minut wprost mówi się, że główna aktorka (w tym wypadku Marina Vlady) wciela się w kogoś innego.

${ }^{45}$ Więcej o Lekcjach historii w kontekście brechtianizmu można znaleźć w tekście S. Heatha, From Brecht to Film: Theses, Problems (on "History Lessons" and "Dear Summer Sister"), "Screen” 1975 , t. 16, nr 4, s. 34-45.

${ }^{46}$ Kovács wylicza między innymi następujące filmy: Zeszłego roku w Marienbadzie (L'Année dernière à Marienbad, reż. Alain Resnais, 1961), Gorzkie tzy Petry von Kant (Die Bitteren Tränen der Petra von Kant, reż. Rainer Werner Fassbinder, 1972) czy Hitler - film z Niemiec (Hitler - ein Film aus Deutschland, reż. Hans-Jürgen Syberberg, 1977). Zob. A. B. Kovács, dz. cyt., s. $192-202$.

47 Tamże, s. 192.

48 Tamże, s. 195.

49 Tamże, s. 201.

${ }^{50}$ Komentował to również Jude, zaznaczając, że $\mathrm{w}$ swych filmach sięga do historii przede wszystkim po to, by lepiej zrozumieć dzisiejszą Rumunię i sposób identyfikowania się rodaków z rozmaitymi narracjami (także nacjonalistycznymi). Zob. H. Emmerzael, dz. cyt.; L. Boyce, dz. cyt.

${ }^{51}$ A. Koutsourakis, Rethinking Brechtian Film Theory and Cinema, Edinburgh University Press, Edinburgh 2018.

${ }^{52}$ Pozostałe wskazane przez Koutsourakisa rodzaje filmów to eseje audiowizualne (wśród analizowanych dzieł znalazły się tu m.in. $M a-$ teriat /Material, reż. Thomas Heise, 2009/ i Scena zbrodni /The Act of Killing, reż. Joshua Oppenheimer, 2012/) i utwory reprezentujące „kino okrucieństwa”, inspirowane teatrem Antonina Artauda (Koutsourakis jako przykłady wymienia Klatkę /The Brig, reż. Jonas Mekas, 1964/ i Import/Export /reż. Ulrich Seidl, 2007/).

53 Tamże, s. 150.

${ }^{54}$ Tamże, s. 151. Zacytowane słowa korespondują z jedną z tez przywołanego już wcześniej Pierre'a Sorlina, który w swoim szkicu odnotowywał, że Film historyczny "umieszcza w teraźniejszości" zdarzenia przeszłe i w ten sposób zyskuje silne zabarwienie polityczne. Zob. P. Sorlin, Klio na ekranie albo historyk w mroku, tłum. J. Galewska, „Film na Świecie” 1980, nr 4 (260), s. 53.

${ }^{55}$ R. Rosenstone, History on Film / Film on History, Pearson Longman, Harlow 2006, s. 118.

${ }^{56}$ Słowa Macieja Białousa piszącego w kontekście kina historycznego, że na ekranie brak dekoracji jest równie zauważalny, jak ich obecność, a może nawet bardziej, narażając obraz na zarzut teatralnej umowności, wydają się szczególnie znamienne, jeśli wziąć pod uwage Drukowanymi literami. Tyle że w tym wypadku nie można teatralnej umowności traktować jako zarzutu, bo ta jest jego cechą immanentną. Por. M. Białous, Społeczna konstrukcja filmów historycznych. Pamięć zbiorowa i polityka pamięci w kinematografii polskiej, Wydawnictwo Naukowe Katedra, Gdańsk 2017, s. 26.

${ }^{57}$ Konflikt tych postaci należy do bardziej fascynujących wątków filmu Judego. Movila, choć jest strażnikiem określonej polityki kulturalnej, nie został tu sportretowany jako bohater negatywny, mimo że do pewnego momentu może tak się wydawać. Z jednej strony reprezentuje on oficjalną narrację historyczna, wyraźnie stroniącą od niewygodnych faktów dotyczących zaangażowania państwa rumuńskiego w zagładę Żydów oraz chętnie skupiającą się na refleksji nad czasami komunizmu w kraju, z drugiej potrafi wytknąć Marianie naiwną wiarę w sztukę zdolną odmienić poglądy odbiorców. Niejednoznaczność postaci podkreślają także ostatnie sekwencje filmu. 
Jeszcze przed premierą ulicznego przedstawienia Mariany Movila stawia jej ultimatum (żąda, aby usunęła z niego wątki jednoznacznie wskazujące, że Rumunia czasów Antonescu jest odpowiedzialna za wymordowanie setek niewinnych ludzi), zamykając jej możliwości przygotowania rekonstrukcji w takim kształcie, do jakiego dążyła. W trakcie premierowego przedstawienia widać jednak, że Mariana zdecydowała się zaakcentować wątki historyczne. Movila nie karze jednak bohaterki - po wszystkim gratuluje artystce (Podobaja mi się wyrazy artystycznej niesubordynacji), wręcza jej książkę o masakrze historycznej, o której nie słyszała i zaprasza zdumioną Marianę na lampkę wina.

${ }^{58}$ Jude żałował, że nie posłużył się teleprompterem, który wyświetlałby aktorom linie dialogowe, co nie tylko ułatwiłoby im pracę, ale także, jak można przypuszczać, spotęgowało efekt obcości. https://www.youtube.com/watch?v=EXE5w8PdQOk (dostęp: 1.06.2021).

${ }^{59}$ Kino found footage - odnotowywała Paulina Haratyk - z zasady nakierowane jest na przeszłość, która stara się na nowo ukazać $i$ zdefiniować. P. Haratyk, Found footage: o niezwykłym uroku „obrazów z odzysku”, „Ekrany” 2011, nr 3-4, s. 76.

${ }^{60}$ Nie pierwszy to raz, kiedy tego typu poetyka zostaje w tym celu wykorzystana. Według Michaela Zryda kino "found footage" jest metahistoryczna forma komentowania kulturowych dyskursów $i$ narracyjnych paradygmatów historii. Zob. M. Zryd, Found Footage Film as Discursive Metahistory. Craig Baldwin's "Tribulation 99", „The Moving Image” 2003, t. 3, nr 2, s. 42.
${ }^{61}$ P. Haratyk, dz. cyt., s. 73.

${ }^{62}$ Zob. więcej na ten temat: P. Krajewski, Obrazy $z$ recyklingu, obrazy z odzysku. Remiks, sampling, scratching... O kinie found footage, w: WIDOK. WRO Media Art Reader 1. Od kina absolutnego do filmu przyszłości. Materiały z historii eksperymentu w sztuce ruchomego obrazu, red. V. Kutlubasis-Krajewska, P. Krajewski, Fundacja WRO Centrum Sztuki Mediów, Wrocław 2009, s. $72-81$.

63 Veronica Lazăr i Andrei Gorzo odczytywali już Nie obchodzi mnie... jako film rozwijający poetykę modernizmu politycznego, opisanego wcześniej przez węgierskiego badacza. Zob. V. Lazăr, A. Gorzo, An Updated Political Modernism: Radu Jude and "I Do Not Care If We Go Down in History as Barbarians", "Close Up: Film and Media Studies" 2019, t. 3, nr 1-2, s. 7-19.

${ }^{64}$ Dla porządku warto dodać, że w scenie lektury fragmentów Armii konnej Babla oprócz widocznej książki Bikont widać także powieszony na ścianie obraz Paula Klee zatytułowany Angelus Novus (wiadomo, że należał on do Waltera Benjamina - jednego z filozofów, na których Jude powołuje się najczęściej).

${ }^{65}$ Zob. opinia Wanga Yao, wychodzącego z założenia, że Touch Me Not (reż. A. Pintilie, 2018) i filmy Judego zwiastują zmierzch pewnych tendencji nowego kina Rumunii. W. Yao, Adina Pintilie and the End of Romanian New Wave, „Close Up. Film and Media Studies” 2018, t. 2, nr 2, s. 47-60.

${ }^{66}$ D. Duma, dz. cyt., s. 19.

\section{Paweł Biliński}

Adiunkt w Zakładzie Filmu i Mediów na Uniwersytecie Gdańskim. Autor rozprawy doktorskiej o autotematyzmie w polskim filmie fabularnym. W latach 2012-2019 zajmował się edukacją filmową w Klubie Żak. Był jednym z pomysłodawców i redaktorów internetowego programu o kinie „Amatorzy TV”. Jest stałym współpracownikiem magazynu „Ekrany”. Współredagował książkę Orson Welles. Twórczość - recepcja - dziedzictwo (2016). Publikował między innymi na łamach „Studiów Filmoznawczych”, „Blizy”, „Lampy”, „Panoptikum”, portalu EdukacjaFilmowa.pl oraz w tomach zbiorowych. 


\section{Bibliografia}

Białous, M. (2017). Społeczna konstrukcja filmów historycznych. Pamięć zbiorowa i polityka pamięci w kinematografii polskiej. Gdańsk: Wydawnictwo Naukowe Katedra.

Boyce, L. (2018, 3 lipca). Karlovy Vary Q\&A: Radu Jude on Exploring Romanian Anti-Semitism in New Film „Barbarians”. Screen Daily. https://www.screendaily.com/karlovyvary-qanda-radu-jude-on-exploring-romanian-anti-semitism-in-new-film-barbarians-/5130557.article

Brecht, B. (1975). Wartość mosiadzu (thum. M. Kurecka). Warszawa: Wydawnictwa Artystyczne i Filmowe.

Brecht, B. (1979). Uwagi do opery „Rozkwit i upadek miasta Mahagonny” (thum. E. Misiołek). W: B. Brecht, Dramaty (t. 1). Warszawa: Państwowy Instytut Wydawniczy.

Dąbrowska, D. (2015). Trochę z Cervantesa, trochę z Czechowa (rozmowa z Radu Jude). Kino, (11), ss. 30-31.

Deletant, D. (2005). Rumunia. Zapomniany sojusznik Hitlera (thum. M. Baranowski). Warszawa: Bellona.

Duma, D. (2018). Self-reflexivity in New Romanian Cinema: A Method of Working. Close Up. Film and Media Studies, 2 (2), ss. 7-20.

Durys, E. (2019). Film jako źródło wiedzy historycznej. Warszawa: Wydawnictwo Instytutu Nauki o Polityce.

Emmerzael, H. (2020, kwiecień). Reaching Into History: Radu Jude on „Uppercase Print” and „The Exit of the Trains". Senses of Cinema. https://www.sensesofcinema.com/2020/conversations-with-filmmakers-across-the-globe/radu-jude/

Guynn, W. (2010). Przekształcanie historii w filmie (tłum. T. Rutkowska, K. Kosińska). Kwartalnik Filmowy, (69), ss. 5-30.

Haratyk, P. (2011). Found footage: o niezwykłym uroku „obrazów z odzysku”. Ekrany, (3$-4)$, ss. $73-77$.

Hołobut, A., Woźniak, M. (2017). Historia na ekranie. Gatunek filmowy a przektad audiowizualny. Kraków: Wydawnictwo Uniwersytetu Jagiellońskiego.

Koutsourakis, A. (2018). Rethinking Brechtian Film Theory and Cinema. Edinburgh: Edinburgh University Press.

Kovács, A. B. (2007). Screening Modernism: European Art Cinema, 1950-1980. Chicago: University of Chicago Press.

Rosenstone, R. (2006). History on Film / Film on History. Harlow: Pearson Longman.

Sorlin, P. (1980). Klio na ekranie albo historyk w mroku (thum. J. Galewska). Film na Śriecie, 4 (260), ss. 44-55.

Stojanova, Ch. (2019). Authenticity in New Romanian Cinema: „Ethics and Aesthetics Are One”. W: Ch. Stojanova, D. Duma (red.), The New Romanian Cinema (ss. 123-136). Edinburgh: Edinburgh University Press.

Syska, R. (2015). (Re)konstruowanie pamięci o Rewolucji w nowym kinie rumuńskim. Images, 17 (26), ss. 5-14.

Zryd, M. (2003). Found Footage Film as Discursive Metahistory: Craig Baldwin's „Tribulation 99". The Moving Image, 3 (2). 
Keywords:

Radu Jude;

Romania;

Bertolt Brecht;

reconstruction;

distancing effect;

intertextuality

\section{Abstract \\ Paweł Biliński \\ Studies on History: Radu Jude's Brechtian Films}

The article focuses on the work of the Romanian film director Radu Jude, who continued to examine historical topics after completing Aferim! in 2015. The author presents basic concepts of the historical film (with reference to William Guynn's and Robert Rosenstone's findings) and gives a brief overview of the dominant aesthetics and narratives of Romanian films produced in the $21^{\text {st }}$ century. In this context, the author analyzes I Do Not Care If We Go Down in History as Barbarians (Îmi este indiferent daca în istorie vom intra ca barbari, 2018) and Uppercase Print (Tipografic Majuscul, 2020) - two feature films in which Jude refers to Bertolt Brecht's theory and updates the poetics of modernist cinema. By focusing on historical issues, as analyzed with the use of reflexive modes of storytelling, Jude tries not to follow the thematic tendencies of recent Romanian cinema. 